\title{
Effect of Mulching on Uptake of Copper and Nickel from Smelter-Polluted-Soil by Planted Tree Seedlings
}

\author{
Eva Komanicka $^{1,2}$, Heljä-Sisko Helmisaari ${ }^{3}$, Markus Hartman ${ }^{2}$, Tiina M. Nieminen ${ }^{2}$ \\ ${ }^{1}$ Department of Geochemistry, Faculty of Natural Sciences, Comenius University Bratislava, Bratislava, Slovakia \\ ${ }^{2}$ Finnish Forest Research Institute, Metla, Vantaa, Finland \\ ${ }^{3}$ Department of Forest Sciences, University of Helsinki, Helsinki, Finland \\ Email: tiina.nieminen@metla.fi
}

Received June 5, 2013; revised July 22, 2013; accepted August 2, 2013

Copyright (C) 2013 Eva Komanicka et al. This is an open access article distributed under the Creative Commons Attribution License, which permits unrestricted use, distribution, and reproduction in any medium, provided the original work is properly cited.

\begin{abstract}
Our aim was to determine the long-term effect of a mulching treatment on copper $(\mathrm{Cu})$ and nickel $(\mathrm{Ni})$ uptake by tree seedlings (Pinus sylvestris L. and Betula pubescens Ehrh.) from smelter-polluted forest soil in southwestern Finland. A mulch cover spread onto polluted barren soil did not have a clear positive impact on the biomass production and it did not decrease metal uptake by planted tree seedlings during a ten-year study period. In contrast, the $\mathrm{Cu}$ uptake by the above-ground parts of birch was increased as a result of mulching, although there were weak indications of slightly reduced availability of $\mathrm{Cu}$ and $\mathrm{Ni}$ to roots in the case of both species. As $\mathrm{Cu}$ and $\mathrm{Ni}$ concentrations of foliage and bark have been shown to be strongly affected by surface deposited metal containing aerosols, only the woody compartments were used as indicators of metal uptake from soil. The Cu:Ni ratios of woody compartments were lower than those predicted by the $\mathrm{Cu}: \mathrm{Ni}$ ratios of soil suggesting that the soil extraction method used gives an underestimation of available $\mathrm{Ni}$ in relation to $\mathrm{Cu}$. The lower soil $\mathrm{Ni}_{\text {exch }}$ concentrations on the mulched plots compared to the controls were in agreement with the slightly lower root $\mathrm{Ni}$ concentrations in the mulch treatments.
\end{abstract}

Keywords: Bioavailability; Biocompost; Birch; Forest Soil; Pine; Restoration; Wood Chips

\section{Introduction}

Several methods have been developed to ameliorate site conditions and enhance plant establishment and growth on metal contaminated environments. Different remediation agents, such as lime and fertilizers [1], compost and beringite mixture [2] and application of mulch [3-6] have been used in environmental restoration approaches. In addition to providing nutrients into soil, the high organic matter content of biowaste composts improves the waterholding capacity, cation exchange capacity and nutrient availability of soil, which in turn improve tree growth [7].

Plants reveal different patterns in the uptake of trace elements $[8,9]$. The vascular plants take up elements mainly by their roots from the soil, even if the foliar uptake of gases and soluble elements may also take place [10]. Trees have been suggested as a low-cost, sustainable and ecologically sound solution to the remediation of heavy metal-contaminated land [11]. Benefits arise mainly from stabilization of the soil, but in many cases, trees may be sufficient to provide clean-up of the soil. Before the beneficial effects can be obtained, the trees must become established on a site [12]. However, on highly contaminated soils, tree establishment may be inhibited by metal toxicity. In less contaminated soils, other factors may limit plant growth, such as macronutrient deficiencies [13] and physical conditions, especially those properties leading to poor water holding, aeration and root penetration [14].

The effects of mulching have been reported to vary greatly according to site, plant species and mulch types $[15,16]$. However, only few studies on long-term effects of mulching on plant metal uptake have been reported. It is known from an earlier paper based on our study fields that mulching favored establishment of transplants and enhanced natural recolonization by pioneer species [17]. The aim of this paper was to assess the long-term effect of mulching on biomass production and $\mathrm{Cu}$ and $\mathrm{Ni}$ uptake by seedlings of pine (Pinus sylvestris L.) and birch (Betula pubescens Ehrh.) grown for a ten-year-period on a metal-contaminated site. 


\section{Methodology}

\subsection{Study Site}

The study site at Harjavalta $\left(61^{\circ} 19^{\prime} \mathrm{N}, 22^{\circ} 9^{\prime} \mathrm{E}\right)$, southwestern Finland has been subjected to a heavy pollution load from a large metallurgical complex for several decades. Smelting of copper started in the area in 1945 by Outokumpu Oy, while the nickel smelter and refinery were established in 1959. The surrounding heathland Scots pine forests are suffering from severe needle loss and growth retardation $[18,19]$ and high fine root mortality [20]. The understory vegetation is almost completely degraded [21,22] and even though viable seeds have been found in the forest soil close to the smelters, no seedling rooting takes place [23].

The long term (1960-1990) mean annual temperature at a nearby weather station of the Finnish Meteorological Institute is $+4.0^{\circ} \mathrm{C}$ and the annual precipitation $558 \mathrm{~mm}$. The mean annual temperature and annual precipitation during the study period (1996-2005) were $5.3^{\circ} \mathrm{C} \pm 0.6^{\circ} \mathrm{C}$ and $591 \mathrm{~mm} \pm 62 \mathrm{~mm}$, respectively. The metallurgical plants are located on a forested esker running in a NWSE direction. The soil consists of sorted fine or sorted fine/coarse sand with no stones. The soil was classified as an orthic Podzol [24]. The uppermost part of the forest floor consists of a dark thick layer of undecomposed litter, as a result of strongly retarded microbial activity and impaired mineralization [25].

\subsection{Remediation Experiment}

In June 1996, tree seedlings were planted at a distance of ca. 500 meters from the main stack of the $\mathrm{Cu}-\mathrm{Ni}$ smelters. Seedlings of two native species, Betula pubescens Ehrh. (1-year-old containerized downy birch seedlings) and Pinus sylvestris L. (2-year-old containerized Scots pine seedlings), were each planted on six replicate plots $(5 \times 5$ $\mathrm{m}^{2}$ ) as 49 seedlings per plot. Three of the plots were totally covered with a $5 \mathrm{~cm}$-thick layer of mulch, and the other three were left uncovered to serve as controls. In addition, six replicate plots $\left(5 \times 5 \mathrm{~m}^{2}\right)$ without any transplants were established to serve as reference sites for soil characteristics. Three of them were covered with a 5 $\mathrm{cm}$-thick layer of mulch, and the other three were left uncovered. The location of the experimental plots was randomized. One of the uncovered plots was unintentionally destroyed when slag was spread over it.

The pine and birch seedlings were planted in soil pockets (2 L, depth about $20 \mathrm{~cm}$ ) containing mulch. Planting the seedlings in the mulch pockets penetrating down into the less contaminated soil was considered to be essential for their initial survival [17].

The mulch consisted of a mixture of household biocompost and woodchips (1:1, volume). The biocompost was 14 months old and had been produced in outdoor windrows at the Ämmässuo Waste Handling Centre, Espoo, Finland by mixing kitchen and garden waste from the Greater Helsinki area and coarse woodchips (diameter ca. $50 \mathrm{~mm}$ ). The mulch was prepared one week before spreading by mixing the biocompost with woodchips (diameter $<20 \mathrm{~mm}$ ) of Scots pine and Norway spruce (Picea abies Karst.) stemwood [26]. The $\mathrm{pH}$ of the mulch was 6.3 and the carbon:nitrogen ratio 16:1 [26]. The average $\mathrm{Cu}$ and $\mathrm{Ni}$ concentrations in the Ämmässuo biocompost were 60 and $3 \mathrm{mg} \cdot \mathrm{kg}^{-1}$ as dry weight [26]. The mulch was spread directly on the layer of undecomposed litter with a plotwise dose of biocompost (excluding the woodchips) of $5.4 \mathrm{~kg} \cdot \mathrm{m}^{-2}$ as dry weight. The input of $\mathrm{C}$ through mulching was $2 \mathrm{~kg} \cdot \mathrm{m}^{-2}$ [26].

\subsection{Harvest of the Seedlings and Soil Sampling}

After a 10 year period, 3 seedlings from each experimental plot (3 replicate plots for both control and mulching) were harvested in August 2005. One of the seedlings was chosen among the tallest individuals, the second to represent the smallest ones, and finally the third one to represent the medium size. After removing the foliage, the youngest shoots (formed in 2005) and all roots were separated from the seedlings, and bark was carefully peeled away from the remaining part to obtain 5 compartments: foliage, young shoots, bark, wood, roots. The pine needles were grouped according to the year of their formation: Current, current +1 year, current +2 and current $+3+$ older needles.

The soil samples were collected with an auger (diameter $58 \mathrm{~mm}$ ) at the same time as seedlings were harvested. Three cores per plot were taken and after removing the organic layer the mineral soil was divided in layers of 5-cm-thickness $(0-5,5-10,10-15,15-20,20-25$, and $25-30 \mathrm{~cm})$.

\subsection{Analytical Methods}

The plant samples were dried and weighed. After weighing the three replicates of each compartment from each plot were bulked together to give one composite sample of each compartment per plot, thus resulting in three replicate composite samples per treatment. The organic layer samples of the soil cores were dried and milled to pass through a $1 \mathrm{~mm}$ sieve, and thereafter they were divided into two parts for the total and exchangeable analysis. Total $\mathrm{Cu}$ and $\mathrm{Ni}$ concentrations from the organic soil and plant samples were determined, following microwave assisted wet digestion in $\mathrm{HNO}_{3}$ and $\mathrm{H}_{2} \mathrm{O}_{2}$, by Inductively Coupled Plasma Atomic Emission Spectrometry (ICP-AES).

Exchangeable $\mathrm{Cu}$ and $\mathrm{Ni}$ were determined by extraction with $0.1 \mathrm{M} \mathrm{BaCl}_{2}+2 \%$ EDTA, $(7.5 \mathrm{~g}$ of mulch or $15 \mathrm{~g}$ of mineral soil $/ 150 \mathrm{ml}$ extractant, shaking for 2 
hours) followed by filtration and analysis by ICP-AES.

\subsection{Statistical Analyses}

We used the two way t-test to study the effect of the treatment on biomass and metal concentrations and the between-species variation.

\section{Results}

\subsection{Biomass Production}

There were no statistically significant differences in biomass production during the ten-year period between the mulch and control treatments, although the mean biomasses of both pine and birch tended to be slightly higher on the mulched plots (Figure 1).

\subsection{Metal Concentrations}

\subsubsection{Foliage}

The $\mathrm{Cu}$ and Ni concentrations of pine needles tended to increase with age but no statistically significant differences could be found between the treatments (Table 1). In case of birch the $\mathrm{Cu}$ and $\mathrm{Ni}$ concentrations of the leaves were slightly higher in the mulch treatment, but the differences were not statistically significant (Table 1).

\subsubsection{Bark}

The highest $\mathrm{Cu}$ and $\mathrm{Ni}$ concentrations of all the sampled compartments were those of pine bark from the control plots (Figure 2). The t-test showed that the betweentreatment difference was statistically significant for the $\mathrm{Cu}$ concentrations $(\mathrm{t}=4.039 ; \mathrm{p}=0.016)$.

The mean $\mathrm{Cu}$ concentration of the birch bark was slightly higher on the mulch plots, but the difference was not statistically significant. The corresponding Ni con-

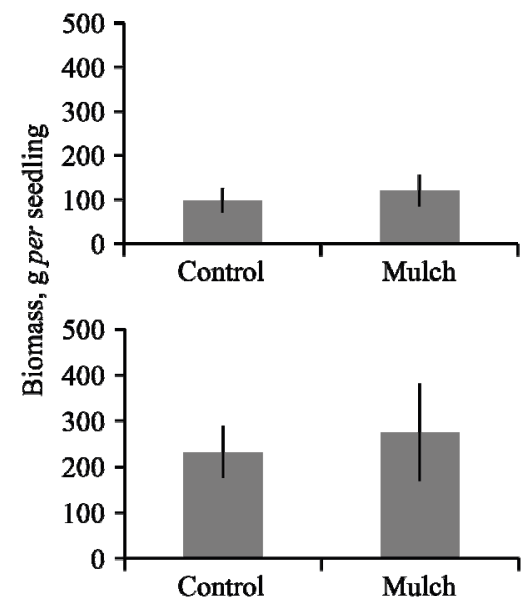

Figure 1. Mean total biomass of the sampled tree seedlings by treatments, $n=9$ for both species. The bar indicates the standard error of the mean.
Table 1. Mean ( \pm standard error of the mean) $\mathrm{Cu}$ and $\mathrm{Ni}$ concentrations of pine needles by needle age classes $(C=$ current needles, $C+1$ one-year-old needles, $C+2$ two-yearold needles and $C+3$ three-year-old needles), $n=3$ in treatments.

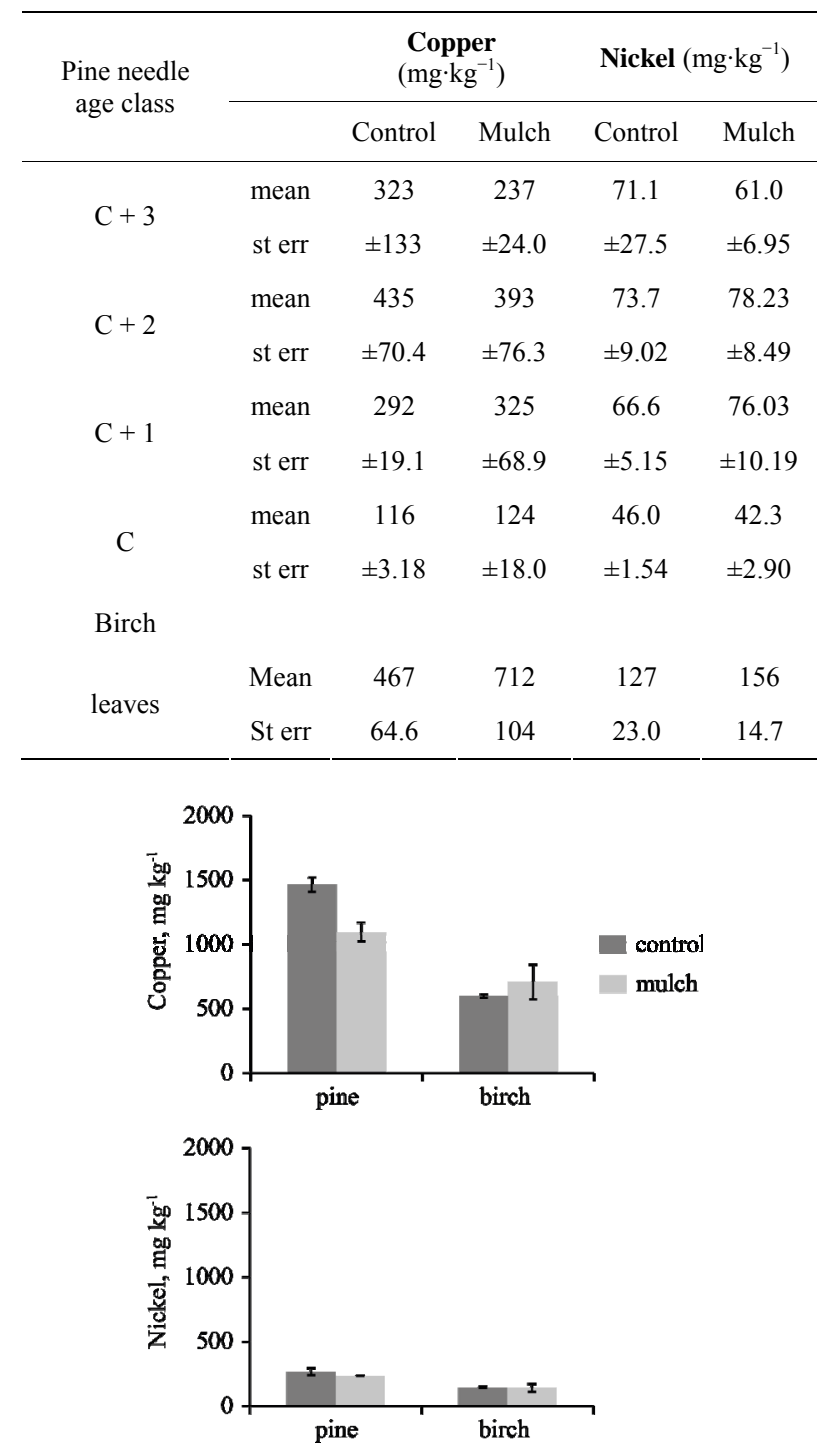

Figure 2. Mean $\mathrm{Cu}$ and $\mathrm{Ni}$ concentrations in bark of pine and birch by treatments, $n=3$. The bar indicates the standard error of the mean.

centrations were about the same for both treatments (Figure 2).

\subsubsection{Above Ground Woody Compartments and Roots}

The $\mathrm{Cu}$ and $\mathrm{Ni}$ concentrations of the youngest shoots were much lower than those of bark, but there were no statistically significant differences between the treatments (Figure 3). The $\mathrm{Cu}$ and $\mathrm{Ni}$ concentrations in pine wood appeared to be slightly higher on the control plots, but the differences were not statistically significant (Fi- 
gure 4).

The mean $\mathrm{Cu}$ and $\mathrm{Ni}$ concentrations in both pine and birch roots were slightly higher on the control plots compared to the mulch treatment, but the differences were not statistically significant (Figure 5).

\subsubsection{Soil Concentrations}

The $\mathrm{Ni}_{\text {exch }}$ concentrations in the mineral soil layers tended to be lower in the mulched plots compared to the control, while the differences between the treatments in the $\mathrm{Cu}_{\text {exch }}$ concentrations of the mineral soil were small (Figure 6). The $\mathrm{Ni}_{\text {exch }}$ concentrations were much lower than the $\mathrm{Cu}_{\text {exch }}$ concentrations, roughly ten times lower.
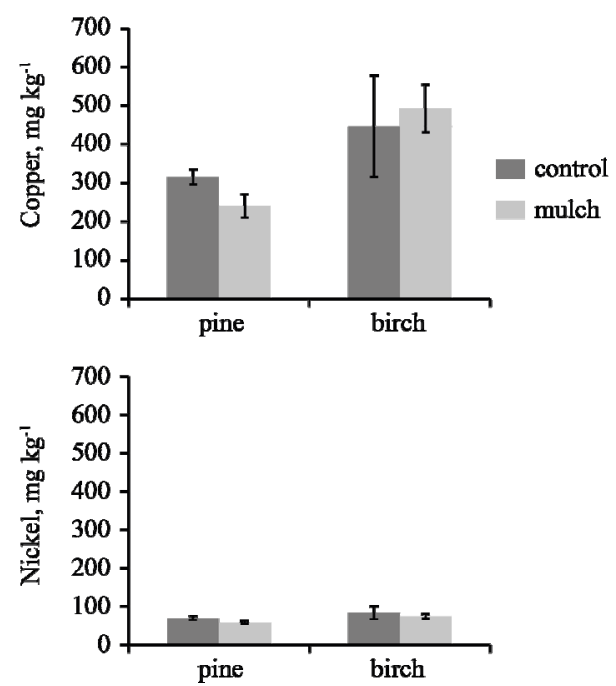

Figure 3. Mean $\mathrm{Cu}$ and $\mathrm{Ni}$ concentrations in the youngest shoots of pine and birch by treatments, $n=3$. The bar indicates the standard error of the mean.
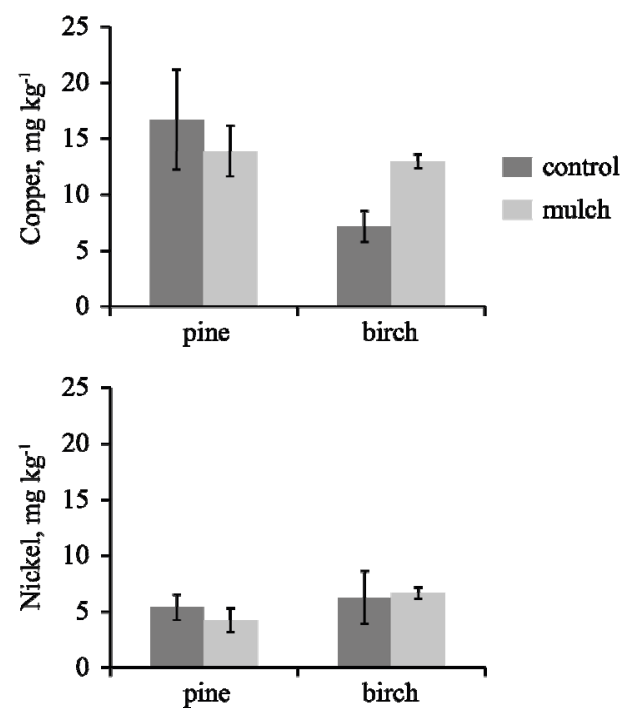

Figure 4. Mean $\mathrm{Cu}$ and $\mathrm{Ni}$ concentrations in wood (without bark) of pine and birch by treatments, $n=3$. The bar indicates the standard error of the mean.

\section{Discussion}

\subsection{Biomass Production and Metal Uptake}

Both Scots pine and downy birch are considered as metal tolerant species, since they are able to survive in metalpolluted areas around smelters [17,27-29]. Restricted uptake of metals by roots and low translocation into foliage is the most common resistance trait [30]. The mulch cover is supposed to restrict the metal uptake of seedlings by orientation of their roots into this layer containing less metals and to protect plant roots from drought and to provide a source of nutrients [17,31]. However, our results are not in agreement with these
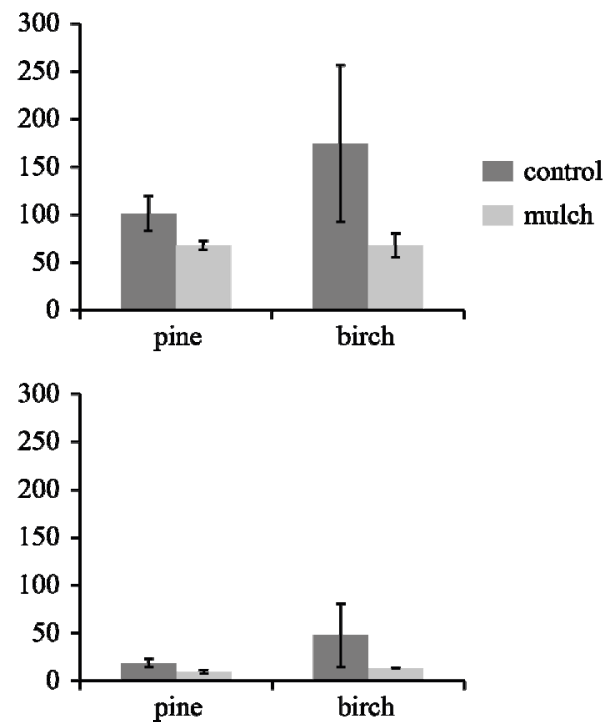

Figure 5. Mean $\mathrm{Cu}$ and $\mathrm{Ni}$ concentrations in roots of pine and birch by treatments, $n=3$. The bar indicates the standard error of the mean.
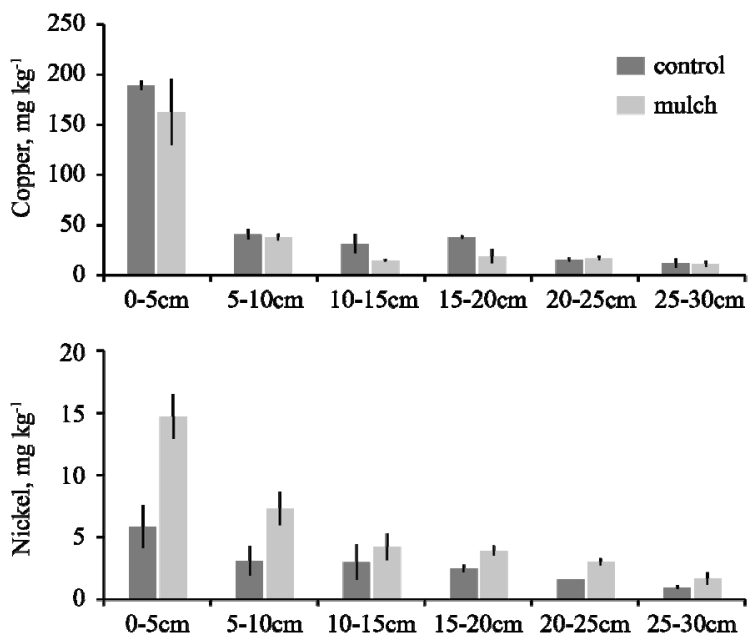

Figure 6. Vertical distribution of mean exchangeable $\mathrm{Cu}$ and $\mathrm{Ni}$ in the soil profile by treatments, $n=3$. The bar indicates the standard error of the mean. Please, note the different scale of the vertical axis for $\mathrm{Cu}$ and $\mathrm{Ni}$. 
earlier findings. We found no enhancement of biomass production by mulching, and the mulch layer did not decrease the availability of $\mathrm{Cu}$ and $\mathrm{Ni}$ to the seedlings. In contrast, the $\mathrm{Cu}$ concentrations in birch wood increased by the mulch treatment. As the root $\mathrm{Cu}$ concentration did not increase, the results suggest increased root-to-shoot mobility of $\mathrm{Cu}$ due to mulching. It appears that some of the $\mathrm{Cu}$ com- pounds formed through complex formation by organic molecules supplied by mulching would be more readily translocated from birch root to shoot than the $\mathrm{Cu}$ forms at the control plots.

\subsection{Soil Extraction as a Predictor of $\mathrm{Cu}: \mathrm{Ni}$ Uptake Ratio}

Clearly more $\mathrm{Cu}$ than $\mathrm{Ni}$ was taken up by pine, which is in agreement with the higher $\mathrm{Cu}$ concentrations in relation to the $\mathrm{Ni}$ concentrations measured from the soil samples. However, the soil $\mathrm{Cu}$ concentrations were almost 10 times higher than the soil $\mathrm{Ni}$ concentrations, while the wood $\mathrm{Cu}$ concentrations of pine were only 3 times higher than those of $\mathrm{Ni}$. In birch, the $\mathrm{Cu}$ and $\mathrm{Ni}$ concentrations in the wood of the control seedlings were equal and in the mulch treated seedlings the $\mathrm{Cu}$ concentrations were only twice as high as those of Ni. Hence, the $\mathrm{BaCl}_{2}+$ EDTA extraction schema used by us as soil extraction method appeared to give an underestimation of both the birch and pine available amount of $\mathrm{Ni}$ in relation to $\mathrm{Cu}$. The $\mathrm{BaCl}_{2}$ method is reported to give an indication of immediately exchangeable metals [32,33], while the use of EDTA has been reported to give a good estimation of potentially plant available metal fractions [34].

\subsection{Surface Deposition Affected $\mathrm{Cu}$ and $\mathrm{Ni}$ Concentrations}

The $\mathrm{Cu}$ and Ni concentrations in the compartments subjected directly to aerial deposition (bark, young shoots, and foliage) were clearly higher than those of wood and roots. A high proportion of these metal concentrations is caused by aerial deposition of dust that accumulates on the plant surfaces and do not penetrate into the living tissues $[18,35,36]$. Thus, high amounts of heavy metals on plant surfaces do not necessarily pose any acute toxic hazard to plant metabolism.

Tree bark is known to sorb and accumulate airborne contaminants and therefore, it has been largely used for monitoring of atmospheric pollution [37-39]. In our study the whole bark layer, including the living inner bark, was taken by peeling it completely from the tree shoots. The inner bark metal concentrations reflect the phloem sap flow. The $\mathrm{Cu}$ and $\mathrm{Ni}$ concentrations in the bark obtained in our study are roughly hundreds of times higher than the nationwide mean values $\left(3.6\right.$ and $1.1 \mathrm{mg} \cdot \mathrm{kg}^{-1}$, respectively) reported by Lippo et al. [35]. Also Saarela et al. [39] found lower metal concentrations $\left(\mathrm{Cu} 89 \mathrm{mg} \cdot \mathrm{kg}^{-1}\right.$ and $\mathrm{Ni} 18 \mathrm{mg} \cdot \mathrm{kg}^{-1}$ ) than our values in Scots pine bark sampled during forest felling 6 kilometers northeast from the Harjavalta smelters.

Scots pine needle $\mathrm{Cu}$ concentrations ranging from 1.7 to $270 \mathrm{mg} \cdot \mathrm{kg}^{-1}$ and $\mathrm{Ni}$ concentrations from 1 to 262 $\mathrm{mg} \cdot \mathrm{kg}^{-1}$ have been found in a $350 \mathrm{~km}$-long transect extending from the Monchegorsk smelter complex, NW Russia, through Finnish Lapland to the Finnish-Swedish border [40-43]. We found even higher concentrations, $\mathrm{Cu}$ ranging from $100-600 \mathrm{mg} \cdot \mathrm{kg}^{-1}$ and $\mathrm{Ni}$ from $50-140$ $\mathrm{mg} \cdot \mathrm{kg}^{-1}$ in our study than the values reported from the Kola gradient.

\section{Conclusion}

The effect of adding a mulch layer on metal availability to tree seedlings was species dependent. The mulching had no clear effect on the $\mathrm{Cu}$ and $\mathrm{Ni}$ availability to pine, while $\mathrm{Cu}$ uptake by birch was enhanced on the mulch treated plots. In addition, although generally more $\mathrm{Cu}$ than $\mathrm{Ni}$ was taken up by the tree seedlings, the Ni uptake rate was higher than what could be predicted on the basis of the ratio of soil exchangeable $\mathrm{Cu}$ and $\mathrm{Ni}$ concentrations.

\section{Acknowledgements}

The present study formed a part of the research project Recovery of Boreal Forest Ecosystem from Long-Term Heavy-Metal Pollution coordinated by Heljä-Sisko Helmisaari at Metla and was partly financed by the Academy of Finland. The authors are grateful to several researchers and staff at Metla for laboratory analysis and assistance in field sampling and production of graphics. We are especially grateful to Oili Kiikkilä, Christian Uhlig, Anne Siika and Sari Elomaa. The work of Eva Komanická has been supported by APVV-0231-07 and UK 373/2012.

\section{REFERENCES}

[1] E. Mälkönen, J. Derome, H. Fritze, H.-S. Helmisaari, M. Kukkola, M. Kytö, A. Saarsalmi and M. Salemaa, "Compensatory Fertilization of Scots Pine Stands Polluted by Heavy Metals," Nutrient Cycling in Agroecosystems, Vol. 55, No. 3, 1999, pp. 239-268. doi:10.1023/A:1009851326584

[2] J. Vangronsveld, V. Colpaert and K. K. Van Tichelen, "Reclamation of a Bare Industrial Area Contaminated by Non-Ferrous Metals: Physico-Chemical and Biological Evaluation of the Durability of Soil Treatment and Revegetation," Environmental Pollution, Vol. 94, No. 2, 1996, pp. 131-140. doi:10.1016/S0269-7491(96)00082-6

[3] E. Muzzi, F. Roffi, M. Sirotti and U. Bagnaresi, "Revegetation Techniques on Clay Soil Slopes in Northern Italy," Land Degradation and Development, Vol. 8, No. 2, 1997, pp. 127-137. 
doi:10.1002/(SICI)1099-145X(199706)8:2<127::AID-LD R248>3.0.CO;2-B

[4] A. Blanco-Garcia and R. Lindig-Cisneros, "Incorporating Restoration in Sustainable Forestry Management: Using Pine-Bark Mulch to Improve Native Species Establishment on Tephra Deposits," Restoration Ecology, Vol. 13, No. 4, 2005, pp. 703-709. doi:10.1111/j.1526-100X.2005.00089.x

[5] J. Dostálek, M. Weber, S. Matula and T. Frantík, "Forest Stand Restoration in the Agricultural Landscape: The Effect of Different Methods of Planting Establishment," Ecological Engineering, Vol. 29, No. 1, 2007, pp. 77-86. doi:10.1016/j.ecoleng.2006.07.016

[6] F. B. Navarro, M. N. Jiménez, E. Gallego and M. A. Ripoll, "Short-Term Effects of Overstorey Reduction and Slash Mulching on Ground Vegetation in a Mediterranean Aleppo Pine Woodland," European Journal of Forest Research, Vol. 129, No. 4, 2010, pp. 689-696. doi:10.1007/s10342-010-0374-3

[7] E. Erhart and W. Hartl, "Mulching with Compost Improves Growth of Blue Spruce in Christmas Tree Plantations," European Journal of Soil Biology, Vol. 39, No. 3, 2003, pp. 149-456. doi:10.1016/S1164-5563(03)00030-X

[8] P. Aronsson and K. Perttu, "Willow Vegetation Filters for Wastewater Treatment and Soil Remediation Combined with Biomass Production," Forestry Chronicle, Vol. 87, No. 6, 2001, p. 797.

[9] A. Kabata-Pendias, "Trace Elements in Soils and Plants," 3rd Edition, CRC Press, Boca Raton, 2001.

[10] H. Marschner, "Mineral Nutrition of Higher Plants," 2nd Edition, Academic Press, London, 1995.

[11] N. M. Dickinson, "Strategies for Sustainable Woodland on Contaminated Soils," Chemosphere, Vol. 4, 2000, pp. 259-263. doi:10.1016/S0045-6535(99)00419-1

[12] I. D. Pulford and C. Watson, "Phytoremediation of HeavyMetal-Contaminated Land by Trees-A Review," Environment International, Vol. 29, No. 4, 2003, pp. 529-540. doi:10.1016/S0160-4120(02)00152-6

[13] I. D. Pulford, C. Watson and S. D. McGregor, "Uptake of Chromium by Trees, Prospects for Phytoremediation," Environmental Geochemistry and Health, Vol. 23, No. 3, 2001, pp. 307-311. doi:10.1023/A:1012243129773

[14] C. E. Mullins, "Physical Properties of Soils in Urban Areas," In: P. Bullock and P. J. Gregory, Ed., Soils in the Urban Environment, Blackwell, Oxford, 1991, pp. 87-118. doi:10.1002/9781444310603.ch6

[15] M. G. Barajas-Guzmán, J. Campo and V. L. Barradas, "Soil Water, Nutrient Availability and Sapling Survival under Organic and Polyethylene Mulch in a Seasonally Dry Tropical Forest," Plant and Soil, Vol. 287, No. 1-2, 2006, pp. 347-357. doi:10.1007/s11104-006-9082-7

[16] Z. Huang, Z. Xu, Ch. Chen and S. Boyd, "Changes in Soil Carbon during the Establishment of a Hardwood Plantation in Subtropical AUSTRALIA," Forest Ecology and Management, Vol. 254, No. 1, 2008, pp. 46-55. doi:10.1016/j.foreco.2007.07.021

[17] H.-S. Helmisaari, M. Salemaa, J. Derome, O. Kiikkilä, C.
Uhlig and T. Nieminen, "Remediation of Heavy MetalContaminated Forest Soil Using Recycled Organic Matter and Native Woody Plants," Journal of Environmental Quality, Vol. 36, No. 4, 2007, pp. 1145-1153. doi: $10.2134 /$ jeq2006.0319

[18] T. M. Nieminen, J. Derome and H.-S. Helmisaari, "Interactions between Precipitation and Scots Pine Canopies along a Heavy-Metal Pollution Gradient," Environmental Pollution, Vol. 106, No. 1, 1999, pp. 129-137. doi:10.1016/S0269-7491(99)00050-0

[19] T. Nieminen, J. Derome, H.-S. Helmisaari, S. Janhunen, M. Kukkola and A. Saarsalmi, "Response of Tree Stands to Heavy Metal Loading," In: E. Mälkönen, Ed., Forest Condition in a Changing Environment-The Finnish Case, Forestry Sciences, Vol. 65, 2000, pp. 278-283. doi:10.1007/978-94-015-9373-1 33

[20] H.-S. Helmisaari, J. Derome, H. Fritze, T. Nieminen, K. Palmgren, M. Salemaa and I. Vanha-Majamaa, "Copper in Scots Pine Forests around a Heavy-Metal Smelter in South-Western Finland," Water, Air, and Soil Pollution, Vol. 85, No. 3, 1995, pp. 1727-1732. doi:10.1007/BF00477229

[21] M. Salemaa, I. Vanha-Majamaa and J. Derome, "Understorey Vegetation along a Heavy-Metal Pollution Gradient in SW Finland," Environmental Pollution, Vol. 112, No. 3, 2001, pp. 339-350. doi:10.1016/S0269-7491(00)00150-0

[22] M. Salemaa, J. Derome, H.-S. Helmisaari, T. Nieminen and I. Vanha-Majamaa, "Element Accumulation in Boreal Bryophytes, Lichens and Vascular Plants Exposed to Heavy Metal and Sulfur Deposition in Finland," The Science of the Total Environment, Vol. 324, No. 1-3, 2004, pp. 141-160. doi:10.1016/j.scitotenv.2003.10.025

[23] M. Salemaa and T. Uotila, "Seed Bank Composition and Seedling Survival in Forest Soil Polluted with Heavy Metals," Basic and Applied Ecology, Vol. 2, No. 3, 2001, pp. 251-263. doi:10.1078/1439-1791-00055

[24] Food and Agriculture Organization of the United Nations (FAO), "Soil Map of the World," World Soil Resources, Policy Report 60, 1988, pp. 1-115.

[25] H. Fritze, P. Vanhala, J. Pietikäinen and E. Mälkönen, "Vitality Fertilization of Scots Pine Stands Growing along a Gradient of Heavy Metal Pollution, Short-Term Effect on Microbial Biomass and Respiration Rate of the Humus Layer," Fresenius' Journal of Analytical Chemistry, Vol. 354, 1996, pp. 750-755.

[26] O. Kiikkilä, J. Perkiömäki, M. Barnette, J. Derome, T. Pennanen, E. Tulisalo and H. Fritze, "In Situ Bioremediation through Mulching of Soil Polluted by a Copper-Nickel Smelter," Journal of Environmental Quality, Vol. 30, No. 4, 2001, pp. 1134-1143. doi:10.2134/jeq2001.3041134x

[27] N. Lukina and V. Nikonov, "Assessment of Environmental impact Zones in the Kola Peninsula Forest Ecosystems," Chemosphere, Vol. 42, No. 1, 2001, pp. 19-34. doi:10.1016/S0045-6535(00)00095-3

[28] E. I. Ermakovand and L. M. Anikina, "Formation of an Organic Compounds and Their Role in Transformation of Mineral Root-Inhabited Media in Regulated Agroecosys- 
tem," Russian Agricultural Sciences, Vol. 6, 2007, pp. 30-32.

[29] O. Kiikkilä, "Remediation through Mulching of Soil Polluted by a Copper-Nickel Smelter," The Finnish Forest Research Institute, Research Papers, Vol. 831, 2002, 57 p.

[30] N. M. Dickinson, A. P. Turner and N. W. Lepp, "How Do Trees and Other and Other Long-Lived Plants Survive in Polluted Environments," Functional Ecology, Vol. 5, No. 1,1991, pp. 5-11. doi:10.2307/2389550

[31] M. Tejada, C. Garcia, J. L. Gonzalez and M. T. Hernandez, "Use of Organic Amendment as a Strategy for Saline Soil Remediation: Influence on the Physical, Chemical and Biological Properties of Soil," Soil Biology and Biochemistry, Vol. 38, 2006, pp. 1413-1421. doi:10.1016/j.soilbio.2005.10.017

[32] P. H. T. Beckett, "The Use of Extractants in Studies on Trace Metals in Soils, Sewage Sludges, and Sludge Treated Soils," In: B. A. Stewart, Ed., Advances in Soil Science, Springer-Verlag, New York, 1989, pp. 143-176. doi:10.1007/978-1-4612-3532-3 3

[33] M. J. McLaughlin, B. A. Zarcinas, D. P. Stewens and N. Cook, "Soil Testing for Heavy Metals," Communications in soil Science and Plant Analysis, Vol. 31, No. 11-14, 2000, pp. 1661-1700.

[34] L. J. Cajuste and R. J. Laird, "The Relationship between the Phytoavailability and the Extractability of Heavy Metals in Contaminatd Soils," In: I. K. Iskander, Ed., Environmetal Restoration of Metals-Contaminated Soils, Lewis Publishers, Boca Raton, 2000, pp. 189-198. doi:10.1201/9781420026269.sec2

[35] M. Turunen, S. Huttunen, K. E. Percy, C. K. McLaughlin and J. Lamppu, "Epicuticular Wax of Subarctic Scots Pine Needles: Response to Sulphur and Heavy Metal Deposition," New Phytologist, Vol. 135, 1997, pp. 501-515. doi:10.1046/j.1469-8137.1997.00675.x

[36] M. V. Kozlov, E. Haukioja, A. V. Bakhtiarov, D. N. Stroganov and S. N. Zimina, "Root versus Canopy Uptake of Heavy Metals by Birch in an Industrial Polluted Area: Contrasting Behaviour of Nickel and Copper," Environmental Pollution, Vol. 107, 2000, pp. 413-420.
doi:10.1016/S0269-7491(99)00159-1

[37] H. Lippo, J. Poikolainen and E. Kubin, "The Use of Moss, Lichen and Pine Bark in the Nationwide Monitoring of Atmospheric Heavy Metal Deposition in Finland," Water, Air, and Soil Pollution, Vol. 85, No. 4, 1995, pp. 22412246. doi:10.1007/BF01186167

[38] L. Harju, K. E. Saarela, J. Rajander, J. O. Lill, A. Lindroos and S. J. Heselius, "Environmental Monitoring of Trace Elements in Bark of Scots Pine by Thick-Target PIXE," Nuclear Instruments and Methods in Physics Research B, Vol. 189, 2002, pp. 163-167.

[39] K. E. Saarela, L. Harju, J. Rajander, J. O. Lill, S. J. Heselius, A. Lindroos and K. Mattson, "Elemental Analyses of Pine Bark and Wood in an Environmental Study," The Science of the Total Environment, Vol. 342, 2005, pp. 231-241. doi:10.1016/j.scitotenv.2004.09.043

[40] N. V. Lukina, V. V. Nikonov and H. Raitio, "Chemical Composition of Pine Needles on the Kola Peninsula," Lesovedenie, Vol. 6, 1994, pp. 1-21.

[41] H. Raitio, J. P. Tuovinen and P. Anttila, "Relation between Sulphur Concentrations in the Scots Pine Needles and the Air in Northernmost Europe," Water, Air, and Soil Pollution, Vol. 85, No. 3, 1995, pp. 1361-1366. doi:10.1007/BF00477171

[42] P. Rautio, S. Huttunen, E. Kukkola, R. Peura and J. Lamppu, "Deposited Particles, Element Concentrations and Needle Injuries on Scots Pines along an Industrial Pollution Transect in Northern Europe," Environmental Pollution, Vol. 103, No. 1, 1998, pp. 81-89. doi:10.1016/S0269-7491(98)00122-5

[43] P. Rautio, S. Huttunen and J. Lamppu, "Element Concentrations in Scots Pine Needles on Radial Transects across a Subarctic Area," Water, Air, and Soil Pollution, Vol. 102, No. 3-4, 1998, pp. 389-405.

[44] T. Hu and J. P. Desai, "Soft-Tissue Material Properties under Large Deformation: Strain Rate Effect," Proceedings of the 26th Annual International Conference of the IEEE EMBS, San Francisco, 1-5 September 2004, pp. 2758-2761. 